\title{
Benthic diatom communities in high altitude lakes: a large scale study in the French Alps
}

\author{
Léa Feret ${ }^{1,2}$, Agnès Bouchez ${ }^{1}$ and Frédéric Rimet ${ }^{1, *}$ \\ ${ }_{1}$ UMR Carrtel, INRA, Université de Savoie, 75 av. de Corzent - BP 511, 74203 Thonon-les-Bains cedex, France \\ ${ }^{2}$ Eurofins Expertises Environnementales, Rue Lucien Cuenot - Site Saint-Jacques II, 54521 Maxéville, France
}

Received: 15 June 2017; Received in final form: 13 October 2017; Accepted: 16 October 2017

\begin{abstract}
Altitude lakes are weakly impacted by human activities. This makes them choice ecosystems to understand how biological communities are impacted by natural factors. This question was addressed to littoral benthic diatoms, a largely used ecological indicator. We wanted to know if benthic diatoms in lakes are more impacted by local varying factors (altitude, lake depth...) or regional varying factors (geology). The study area takes place in the Northern French Alps. Littoral benthic diatoms of 63 natural lakes situated between 1350 and $2700 \mathrm{~m} \cdot$ a.s.l. were sampled. Two categories of communities were observed: one of deep and lower altitude lakes and one of higher altitude and shallower lakes. In each category, communities were characterized and were corresponding to particular lake types: lakes dominated by a particular geology, lakes with a water level fluctuation, turbid lakes,... Communities did not show a spatial structure. We observed that local factors were more important than regional factors. Indeed, the study area displayed a mixed geology even at a local level. On another hand, altitude a local varying factor determines freezing period a determining item of high-altitude lake functioning.
\end{abstract}

Keywords: Bacillariophyta / high altitude lakes / shoreline / structuring parameters / water framework directive

\section{Introduction}

Bacillariophyta (diatoms) is a clade of microalgae which is widely distributed through all types of water bodies. Diatoms are a key component of aquatic ecosystems because they are usually the dominating primary producers (Mann and Droop, 1996). Moreover, benthic diatoms are also known as the main element of phytobenthos both in terms of biomass (Stevenson, 1998) and species diversity: more than 1,00,000 species exist on the earth (Mann and Vanormelingen, 2013) and 700 species are commonly found in European freshwater ecosystems (Lange-Bertalot et al., 2013). Diatoms have a short generation time and each species has particular tolerances to organic matter and nutrients (Crossetti et al., 2013; Rimet et al., 2016). These characteristics make them excellent candidates to be ecological indicators. Indeed the first studies demonstrating the effect of pollution on freshwater diatom diversity was over a century ago (Kolkwitz and Marsson, 1908) and 40-50 years after, several authors proposed methodologies based on the taxonomic composition of diatom communities to assess pollution mostly in rivers (e.g. Butcher, 1947; Hustedt, 1957; Zelinka and Marvan, 1961). Subsequently, hundreds of studies

\footnotetext{
*Corresponding author: frederic.rimet@inra.fr
}

demonstrated the high sensitivity of this class to anthropogenic pressures (Rimet and Bouchez, 2012a). This convinced water authorities to use benthic diatoms in their legislation to assess the ecological quality of freshwater ecosystems. Indeed, since 1972 in the United States with the Clean Water Act and since 2000 in Europe with the Water Framework Directive, water legislators require to assess the ecological quality of water ecosystems with ecological indicators, among which are diatoms. Many biotic indices, such as the Biological Diatom Index in France (Coste et al., 2009) were developed and are now standardized and routinely applied. More effort has been done to improve the monitoring using benthic diatoms in rivers than in lakes (Cantonati and Lowe, 2014). However, from several years things changed and some authors applied existing river diatoms indices to the littoral zone of lakes (Blanco et al., 2004; Bolla et al., 2010; Cellamare et al., 2011) while others developed new tools based on diatoms communities (Schaumburg et al., 2007; Stenger-Kovács et al., 2007; Marchetto et al., 2013; Bennion et al., 2014) to respond to the demands of lakes assessment. Indeed, whereas phytoplankton is considered as the main ecological indicator on lakes, and usually is used to assess the overall lake quality, littoral diatoms demonstrated their efficiency to assess point source pollution and to be early warning of lake's deterioration (Cantonati and Lowe, 2014; Rimet et al., 2016). Moreover, they can show a better ability to 
assess lake's trophic level than pelagic phytoplankton (Rimet et al., 2015). Therefore, use of diatom indices is a complementary of ecological indicator lakes assessment with phytoplankton.

Lakes are often at the crossroads of multiple societal and economic challenges and most of them are under strong anthropogenic pressure and suffer growing eutrophication $(e$. g. Ostendorp et al., 1995; Millennium Ecosystem Assessment, 2005). High-altitude lakes are among the least impacted lakes largely because they are characterized by an altitude level above 800 meters a.s.l. (Parlement européen et al., 2000) and in such altitudes, human activity is much lesser. Moreover, compared to the other lakes, they can be considered as young and extreme ecosystems (Zaharescu et al., 2016). The elevated topography, the low ions and nutrients contents and the strong climate control make them particular ecosystems where a limited number of species are able to develop (Magnea et al., 2013; Zaharescu et al., 2016). With more than 50,000 high-altitude lakes across Europe (Kernan et al., 2009), a number of studies were conducted to understand the functioning of these lakes (e.g. Patrick et al., 1998; Battarbee et al., 2002) and several key results can be highlighted. First, high-altitude lakes have an important patrimonial value due to the small anthropogenic pressure they suffer compared to other lakes. Thus unique plant and animal communities are living around and within these ecosystems (Kernan et al., 2009; Magnea et al., 2013). Second, due to this low impacted character, high-altitude lakes are considered as excellent sensors of environmental changes because of their sensitivity to acid deposition (e.g. Jones et al., 1993; Curtis et al., 2009), persistent organic pollutants deposition (Grimalt et al., 2009), trace metals (Camarero et al., 1995, 2009), greenhouse gases and climate change (e.g. Beniston et al., 1997). All these global factors affect several chemical and biological characteristics within high-altitude lakes such as species distribution and nutrient cycling (e.g. Parker et al., 2008).

Several studies highlighted that natural factors which impact benthic diatoms are minimized because anthropological pressure leads on a homogenization of the communities (e.g. Pan et al., 2000; Leira and Sabater, 2005; Tornés et al., 2007). Therefore, because high-altitude lakes are profuse and known to be pristine, these ecosystems appear to be good study sites to analyze the influence of natural parameters on benthic diatoms communities. Moreover, as high-altitude lakes are preserved but endangered ecosystems, applying benthic littoral diatoms to assess anthropogenic pressure is also an objective to take into consideration and which meet the requirements of the natural area managers (National Parks, Conservatory of natural spaces) and the Water Framework Directive. Many studies already demonstrate the influence of natural and/or regional parameters on communities of diatoms such as dominant geology of the catchment area in rivers (Kernan et al., 2009; Rimet, 2009; Soininen, 2004, 2012), the latitudinal gradient (Vyverman et al., 2007) or the climate change in high-altitude lakes (Kernan et al., 2009). Therefore, to respond to the problematic "Are the communities of benthic diatoms in high altitude lakes more structured by local or regional parameters?" this study will focused on two main objectives:

- describe the different communities of benthic diatoms in high-attitude lakes;
- study the main structuring parameters, through regional and local drivers, of these communities. Regional factors include geology, concentrations in calcium, magnesium, sodium, chloride and sulfate and geographical lakes coordinates whereas local parameters are altitude, depth, nutrients, dissolved organic carbon and suspended matter concentrations, $\mathrm{pH}$.

According to the previous studies in particular in rivers (e.g. Rimet, 2009; Soininen, 2004), the expected conclusions are that littoral benthic diatom communities in high-altitude lakes will be more structured by regional parameters.

We applied this question to 62 high-altitude lakes situated in the Northern French Alps, with an altitude situated between 1350 and $2700 \mathrm{~m} \cdot$ a.s.l. Samplings were carried out once, in summer 2013. Then diatom communities will be explored using a cluster analysis and their structuring parameters will be defined using multivariate analyses.

\section{Materials and methods}

\subsection{Study area and sampling strategy}

The study area is situated in the French Alps. This mountain chain is $350 \mathrm{~km}$ north-south and is composed by two main areas. First, the Southern Alps are characterized by low mountains and a meteorology close to the Mediterranean climate. Annual precipitations range from 850 to $1000 \mathrm{~mm}$ (Meteo France, 2016). Second, the Northern Alps are higher and present wetter climate with annual precipitations ranging from 1200 to $1500 \mathrm{~mm}$ (Meteo France, 2016). There are more than six hundred lakes showing diverse typologies (geologies, altitudes, size, etc.) in this mountain chain.

Thirteen mountain massifs in the Northern Alps were sampled. A massif is composed by several mountains and delimited morphologically by valleys. The aim of this study was to study a large range of high-altitude lakes with low anthropogenic pressure. Therefore, 62 natural lakes localized above $1300 \mathrm{~m} \cdot$ a.s.l. and which have a surface area higher than $3000 \mathrm{~m}^{2}$ were sampled (Fig. 1). Reservoirs or lakes of human origin were excluded.

The study area stretches from $46^{\circ} 16^{\prime}$ to $45^{\circ} 03^{\prime}$ of latitude. Sampled lakes present different characteristics. Approximately $55 \%$ of the lakes catchment areas have a siliceous geology whereas $38 \%$ have a calcareous geology. $57 \%$ of the lakes had one or two refuges in their catchment area. Pastoralism is the dominant activity in $27 \%$ of the studied lakes but can also be absent from the catchment area (17.5\%). Different limnological, physical and chemical characteristics of lakes are given in Table 1.

\subsection{Sampling and laboratory procedures}

Benthic diatoms were sampled according to the guidance protocol (King et al., 2006) in summer (July 2013). One sample was collected per lake. The sampling station had to be in light and far away as possible from effluent arrivals, peatlands and refuges. Five stones were collected at $40-50 \mathrm{~cm}$ depth and their upper surface was scraped using a tooth brush. The biofilms collected were handled as a composite sample and fixed with $70 \%$ ethanol before being treated according to 


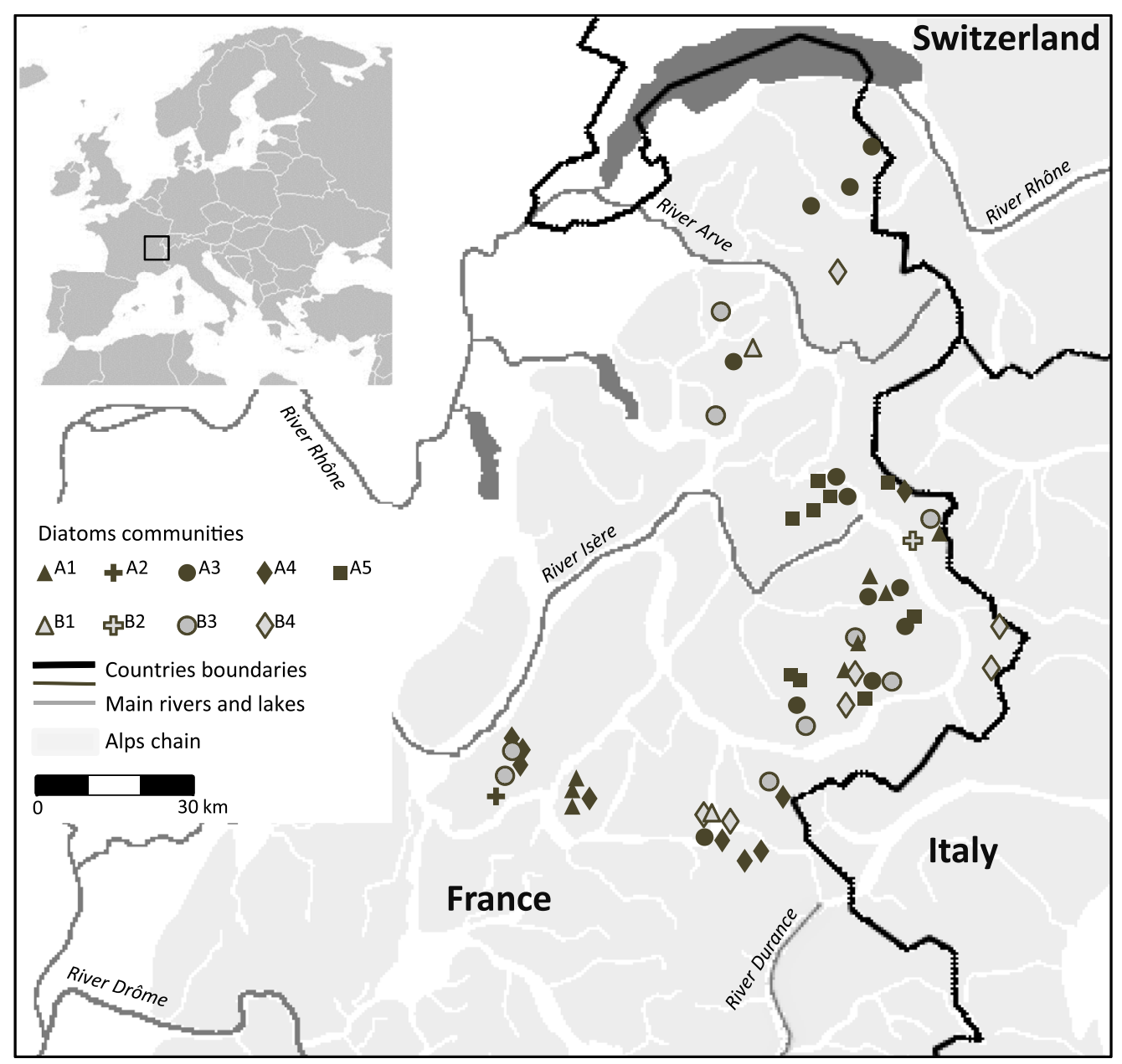

Fig. 1. Location of the study area and of the lakes. The diatom community of each lake is given.

the European standard EN 13946 (Afnor, 2003) using $\mathrm{H}_{2} \mathrm{O}_{2}$, $\mathrm{HCl}$ and Naphrax to assemble permanent slides. Four hundred of frustules per sample were finally counted and identified at the species level according to EN 14407 (Afnor, 2014) using classical European floras (Krammer, 1997a, 1997b; Krammer and Lange-Bertalot, 1997; Krammer, 2000, 2002; Krammer and Lange-Bertalot, 2004; Krammer et al., 2008; Krammer and Lange-Bertalot, 2010). Benthic diatoms and chemical samples were collected at the same time: an integrated sample of water was collected in the middle of the lake with a Van Dorn's bottle. Chemical analyses were carried out following standard procedures (APHA, 1995). Conductivity, $\mathrm{pH}$ and temperature were measured in the field with a probe.

Physical and environmental characteristics were also recorded. Altitude, lake size, catchment area size and geology were extracted from maps and from digital terrain models. Maximal depths were found in bibliography.

\subsection{Statistical analysis}

To define benthic diatoms communities in high-altitude lakes a clustering analysis was carried out. Therefore, main diatoms assemblages composed by groups of lakes with homogeneous taxonomic compositions were determined with TWINSPAN (Hill, 1979). Classifications obtained were tested with MRPP (Mielke et al., 1981) which allowed to choose the best classification thanks to A and $p$ values. A value describes the homogeneity within a group. Then, each group of lakes has been characterized by mean communities of benthic diatoms and ranges of chemical and environmental parameters. Thus, boxplots were created for each parameter and each diatom community. Moreover, for each diatom community, its composition in ecological guilds and in saprobic classes (Van et al., 1994) was defined using the database of Rimet and Bouchez (2012b). Box-plots were drawn for each ecological guild and saprobic class. An Indicator Species Analysis (Dufrêne and Legendre, 1997) was also used to characterize indicator species of each group of lakes. All these analyses were realized with PC-ORD software (McCune and Mefford, 2006).

To determine the main structuring parameters of diatoms communities in high-altitude lakes, CCA were realized on the entire database (biological, chemical and environmental data). Chemical and environmental data were firstly standardized. These analysis were realized with PAST software (Hammer et al., 2015).

\section{Results}

A total of 326 diatom taxa were identified at the species or sub-species level on 62 diatoms samplings (one sampling per lake). The diatom communities of high-altitude lakes were 
Table 1. Summary of mainslimnological, physical and chemical parameters in the sampled high-altitude lakes.

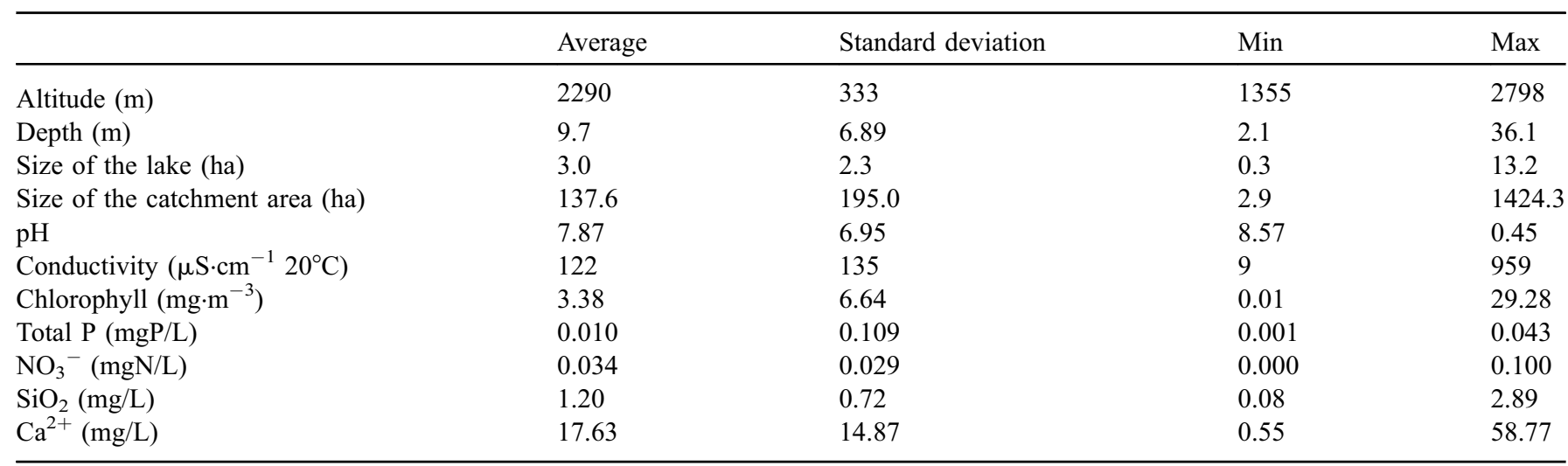

dominated by the genera Achnanthidium, Encyonema, Encyonopsis, Denticula, Staurosirella and Navicula. The most common and abundant species was Achnanthidium minutissimum (Kützing) Czarnecki. This species was identified in 62 lakes and its average abundance is $21.8 \%$. Likewise, Encyonema minutum (Hilse) Mann was observed in 60 lakes and represented on average $10.2 \%$ of the diatom communities in high-altitude lakes. Encyonopsis subminuta Krammer \& Reichardt and Denticula tenuis Kützing were also common and dominant species because they were respectively observed on 50 and 49 lakes with mean averages of 6 and $7 \%$ of the frustules observed on these sites. The others main species were E. ventricosum (Agardh) Grunow (48 lakes, 4.3\%), Cymbella excisa Kützing (46 lakes, 2.7\%) and Staurosirella pinnata (Ehrenberg) Williams \& Round (35 lakes, 4\%).

\subsection{Description of benthic diatom communities}

The results of MRPP applied on Twinspan's classifications showed a global increase in the A-value (statistic measuring group homogeneity) as the number of clusters increases. However because of the highly significant A-value $(p<0.001)$ a total of 9 groups of lakes was chosen. These groups gather from 1 to 12 lakes. Figure 2 shows that the final Twinspan's classification. We explained these clusters using biological, chemical, physical and environmental parameters available for this study. Characterization of each group was made thanks to the analysis of mean communities, especially with dominant and indicative species (Tab. 2), but also from box-plots of the ecological guilds, saprobic classes composition (Fig. 3) and of environmental parameters (Fig. 4) and for the 9 diatom assemblages.

The two first communities (A and B) were distinguished by the depth of the lakes. Then, inside community $A$, lakes are separated according to their trophic level (A1, A4) and their geology (A3, A4 and A5). Inside community B two communities (B1 and B2) were separated because they presented aerophilic and subaerial species and the last two communities (B3 and B4) are characterized by a particular typology. Precise descriptions and references to literature are given in the first section of the discussion.

\subsection{Main structuring parameters}

A canonical correspondence analysis (CCA) was produced to identify the main structuring parameters of benthic diatom communities. It was applied on all lakes, parameters and species. Figure 5a shows that the main structuring parameters on the first axis are one the positive side lake depth, magnesium and silica concentrations; on the negative side sulfate concentration, depth and altitude. On the second axis, on the positive side the most structuring parameter is lake size and on the negative side calcium concentration. From this first analysis a second graph (Fig. 5b) was realized to compare distribution of each main group of lakes (A and B). This one highlighted a separation between the two clusters along axis 1 ( $13.45 \%$ of inertia). Indeed, group A is positively correlated to axis 1 , contrary to group B. The main structuring parameters of this axis are the depth, the silica and magnesium concentrations on the right and the sulfates and suspended matter concentrations with the altitude on the left. Therefore lakes of the group A are deep with high magnesium and silica concentrations whereas lakes of the group B have a higher altitude and higher concentrations in sulfates and suspended matter.

\section{Discussion}

\subsection{Description of the benthic diatom communities}

Two main diatom communities were observed: first, diatom communities of deeper lakes with lower altitudes (communities A); secondly those of shallower lakes with higher altitudes (communities B). Both communities can be subdivided into smaller ones which are presented here down.

\subsubsection{Diatom communities of deeper lakes (A)}

\subsubsection{Diatom communities of oligotrophic lakes on various geologies (A1)}

This diatom community is present in lakes scattered in several mountain chains. These lakes display diverse altitudes, geologies and depths. But based on their low nutrient level they can be considered as ultra-oligotrophic to oligotrophic lakes (Organisation de coopération et de développement économiques, 1982). This community is composed mainly by low- 


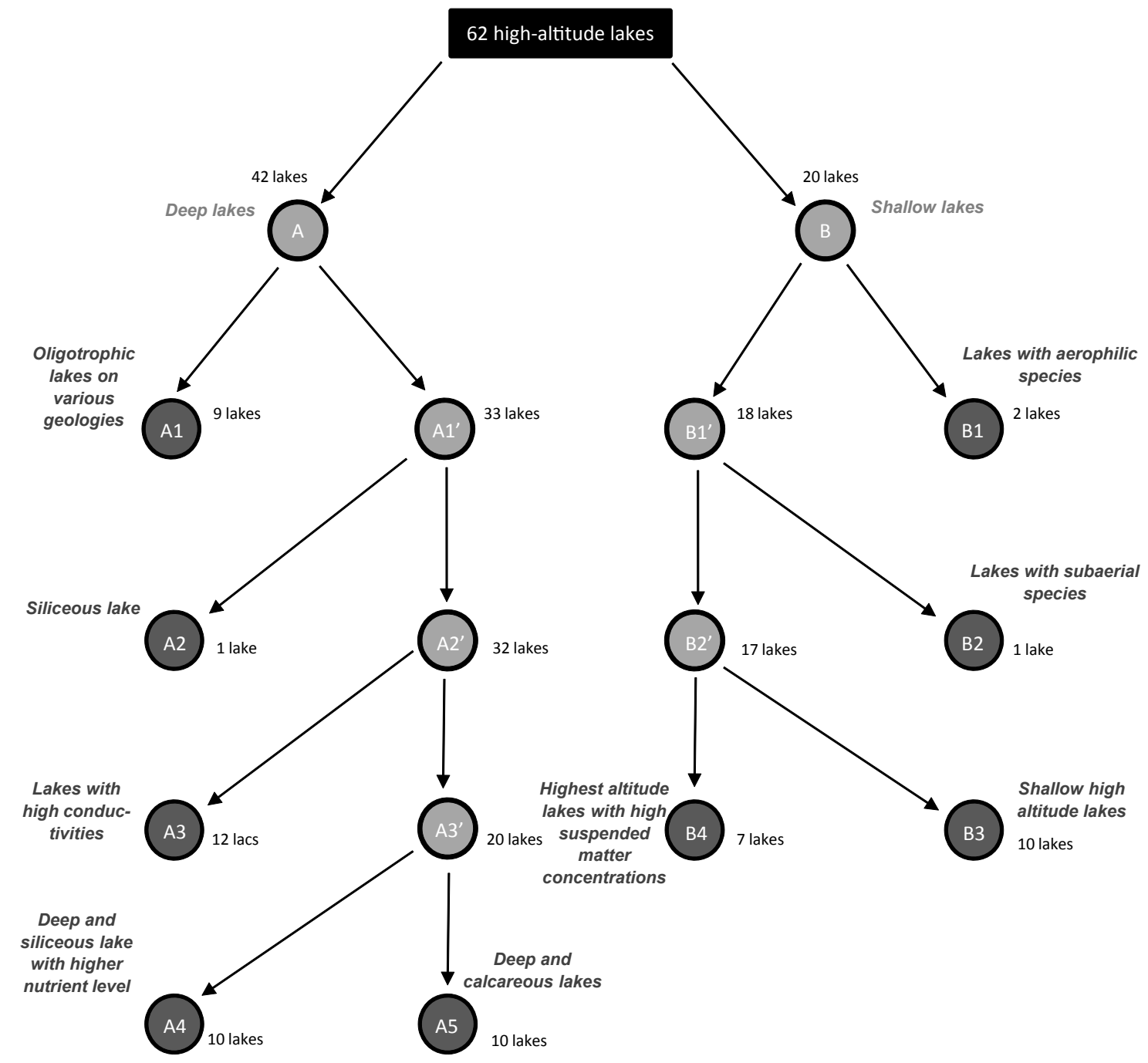

Fig. 2. Groups of samples defined on the basis of their diatom composition. The groups were calculated using a Twin span analysis.

profile $(54.7 \%)$ and $\beta$-mesosaprobic $(42.4 \%)$ species such as A. minutissimum and E. minuta (Van et al., 1994). These two species are often observed in oligotrophic lakes (e.g. Acs et al., 2003). A. minutissimum have a rather wide ecological amplitude (Van et al., 1994; Acs et al., 2003)and is considered as an early colonizer quickly growing when biofilms are scoured (Rimet et al., 2009). E. minutum as well as D. tenuis were also abundant in this group and are mostly found in ecosystems with low nutrients concentrations (Van et al., 1994; Hofmann et al., 2011). The dominant and indicative taxa of this group are usually observed in calcareous environments: it is the case of E. minutum (Rimet et al., 2003; Gomà et al., 2005), D. tenuis (Sabater and Roca, 1992), Brachysira vitrea (LangeBertalot and Moser, 1994) and Cymbella subleptoceros (e.g. Bahls, 2016).

\subsubsection{Diatom communities of siliceous lake (A2)}

Only one lake, lake Achard (situated in Belledonne's mountain chain) compose this particular diatom community. Its water presented a very low conductivity $(37 \mu \mathrm{S} / \mathrm{cm})$ and is surrounded by a siliceous bedrock. Its community is mainly composed by low-profile (57.1\%) diatoms, and its species composition is dominated by A. subatomoides, A. minutissimum and Staurosira venter. A. subatomoides is a clear indicator of low conductivities and of siliceous geologies, since it has already been regularly observed in rivers flowing on limestones (Rimet et al., 2004) or granites geologies (Rimet, 2009).

\subsubsection{Diatom communities of higher conductivities lakes (A3)}

This community is present in lakes of a wide variety of mountain chains and presenting a variety of typologies and nutrients levels. Nevertheless, their common characteristic is to have relatively high water conductivities $(223 \mu \mathrm{S} / \mathrm{cm}$ on average). The diatom community is dominated by low-profile $(46.6 \%)$ and $\beta$-mesosaprobous (46.6\%) diatoms (Van et al., 1994; Rimet and Bouchez, 2012b). Among the dominant species, which are A. minutissimum, E. subminuta, Staurosirella pinnata and $D$. tenuis, two of them are indicators of these relatively high waters conductivities. Indeed, A. minutissimum and $D$. tenuis have already been recorded as indicator taxa 
Table 2. Dominant species and indicator species for each diatom community. Dominant species are the species with an abundance over $5 \%$ and are given in grey. Stars after the abundance are given if the species is a significant indicator species: $* * *: p<0.001 ; * *: p<0.01 ; *: p<0.05 ;{ }^{+}$: $p<0.1$. Groups A2 and B2 were represented by only one lake therefore indicator species were not possible to calculate for these groups.

Species Abundance (\%)

Group A1

Achnanthidium minutissimum (Kützing) Czarnecki

28.49

Encyonopsis minuta Krammer \& Reichardt

$9.86^{* *}$

Encyonema minutum (Hilse) Mann

9.78

Staurosirella pinnata (Ehrenberg) Williams \& Round

6.77

Denticula tenuis Kützing

Cyclotella comensis Grunow

5.12

Staurosira construens var. binodis (Ehrenberg) Hamilton

$2.86^{*}$

Nitzschiaper minuta (Grunow) Peragallo

$0.66^{*}$

Cymbella subleptoceros Krammer

$0.16^{*}$

Brachysira vitrea (Grunow) Ross

$0.11^{*}$

Group A2

Achnanthidium subatomoides (Hustedt) Monnier, Lange-Bertalot \& Ector

Achnanthidium minutissimum (Kützing) Czarnecki

16.67

Staurosira venter (Ehrenberg) Cleve \& Moeller

7.14

Psammothidium chlidanos (Hohn\&Hellerman) Lange-Bertalot

6.43

Group A3

Achnanthidium minutissimum (Kützing) Czarnecki

20.67

Encyonopsis subminuta Krammer\&Reichardt

$10.03^{+}$

Staurosirella pinnata (Ehrenberg) Williams \& Round

8.74

Denticula tenuis Kützing

Navicula cryptotenella Lange-Bertalot

6.48

Nitzschia vacuum Lange-Bertalot

$2.38^{*}$

Achnanthidium caledonicum (Lange-Bertalot) Lange-Bertalot

$1.96^{*}$

$1.24^{+}$

Group A4

Achnanthidium minutissimum (Kützing) Czarnecki

Denticula tenuis Kützing

12.59

Nitzschia costei Tudesque, Rimet \& Ector

5.98

Achnanthidium lineareSmith

Staurosira construens Ehrenberg

Achnanthidium daonense (Lange-Bertalot) Lange-BertalotMonnier\& Ector

Psammothidium levanderi (Hustedt) Czarnecki

Rossithidium pusillum (Grunow) Round \& Bukhtiyarova

Group A5

Encyonopsis microcephala (Grunow) Krammer

Denticula tenuis Kützing

Encyonopsis subminutaKrammer\&Reichardt

Delicata delicatula (Kützing) Krammer

$5.00^{*}$

Encyonopsis moseri Krammer \& Lange-Bertalot

Encyonema simile Krammer

Group B1

Encyonema minutum (Hilse) Mann

Pinnularia borealis Ehrenberg

Achnanthidium minutissimum (Kützing) Czarnecki

9.68

Hantzschia amphioxys (Ehrenberg) Grunow

$6.68^{* * *}$

Navicular adiosa Kützing

Encyonema caespitosumKützing

$6.18^{* *}$

Cymbella compactaØstrup

Diadesmis contentavar. biceps (Grunow) Hamilton 
Table 2. (continued).

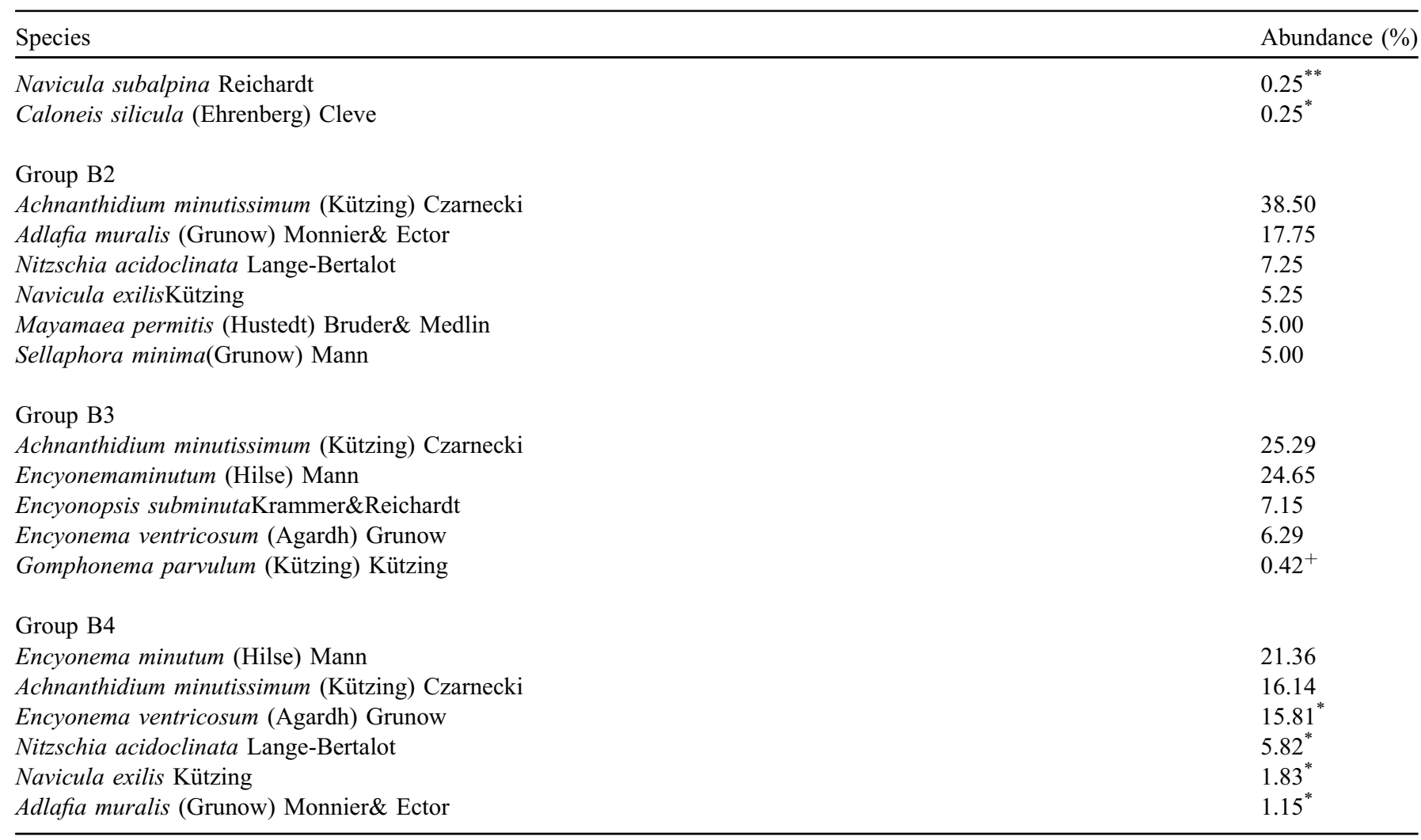

from mineralized rivers in Spanish mountains headwaters (Tornés et al., 2007). Moreover, E. subminuta, which is an indicative species of this community, is usually leaving in calcareous ecosystems (Hofmann et al., 2011).

\subsubsection{Diatom communities of deep siliceous lakes with higher nutrients levels (A4)}

This diatom community is present in lakes of several locations and have in common that they are relatively deep (14 $\mathrm{m}$ depth on average) and have among the lowest conductivities recorded in this study $(64 \mu \mathrm{S} / \mathrm{cm}$ on average). The geology of their catchments areas is siliceous. Another common feature of these lakes is their relatively elevated nutrient level compared to the other lakes of this study $(0.01 \mathrm{mg} / \mathrm{l}$ of total phosphorus). The dominant diatoms are mostly low profiles (47\%) and $\beta$-mesosaprobic (44\%) diatoms (Van et al., 1994; Rimet and Bouchez, 2012b). But an uncommon feature compared to the other diatom communities of this study is the presence of Nitzschia genus among the dominant taxa: Nitzschia costei is usually observed in mesosaprobic and eutrophic rivers of the Loire river basin in western France (Tudesque et al., 2008). Indicative species of this community are $A$. lineare, $A$. daonense, Psammothidium levanderi and Rossithidium pussilum, they are clearly indicators of low conductivities (Sonneman, 2000; Van de Vijver et al., 2011; Hofmann et al., 2011). Even if Nitzschia costei indicates eutrophic waters, the trophic level of these lakes remains modest in an absolute framework, since the majority of the taxa of these lakes are indicators of oligotrophic waters. These results suggest that $N$. costei is probably more ubiquitous that stated in the current literature.

\subsubsection{Diatom community of deep and calcareous lakes (A5)}

This diatom community is present in several lakes scattered in the study area. The common features of these lakes are their important depth and their presence on calcareous bedrocks. This community is dominated by $E$. microcephala, A minutissimum, D. tenuis and E. subminuta. E. microcephala is an indicator of karstic (Reichardt, 1997) and pristine waters (Krammer, 1997a; Potapova and Charles, 2007; Van et al., 1994). E. subminuta shows relatively similar ecological requirements as it was also observed in low impacted and calcareous environments (Van et al., 1994; Hofmann et al., 2011; Bey and Ector, 2013). Moreover, Sabater and Roca (1992) observed that, D. tenuis was abundant in calcareous springs of the Pyrenees. Finally, the indicative specie Delicata delicatula is also characteristic of calcareous ecosystems and indicator of very good water quality (Bey and Ector, 2013). Therefore the diatom species of this community clearly reflects calcareous and oligotrophic lakes.

\subsubsection{Diatom communities of shallower lakes (B)}

\subsubsection{Diatom communities with aerophilic and subaerial} species (B1 and B2)

Diatom community $\mathrm{B} 1$ is present in two lakes of different typologies. However, their particularity compared 

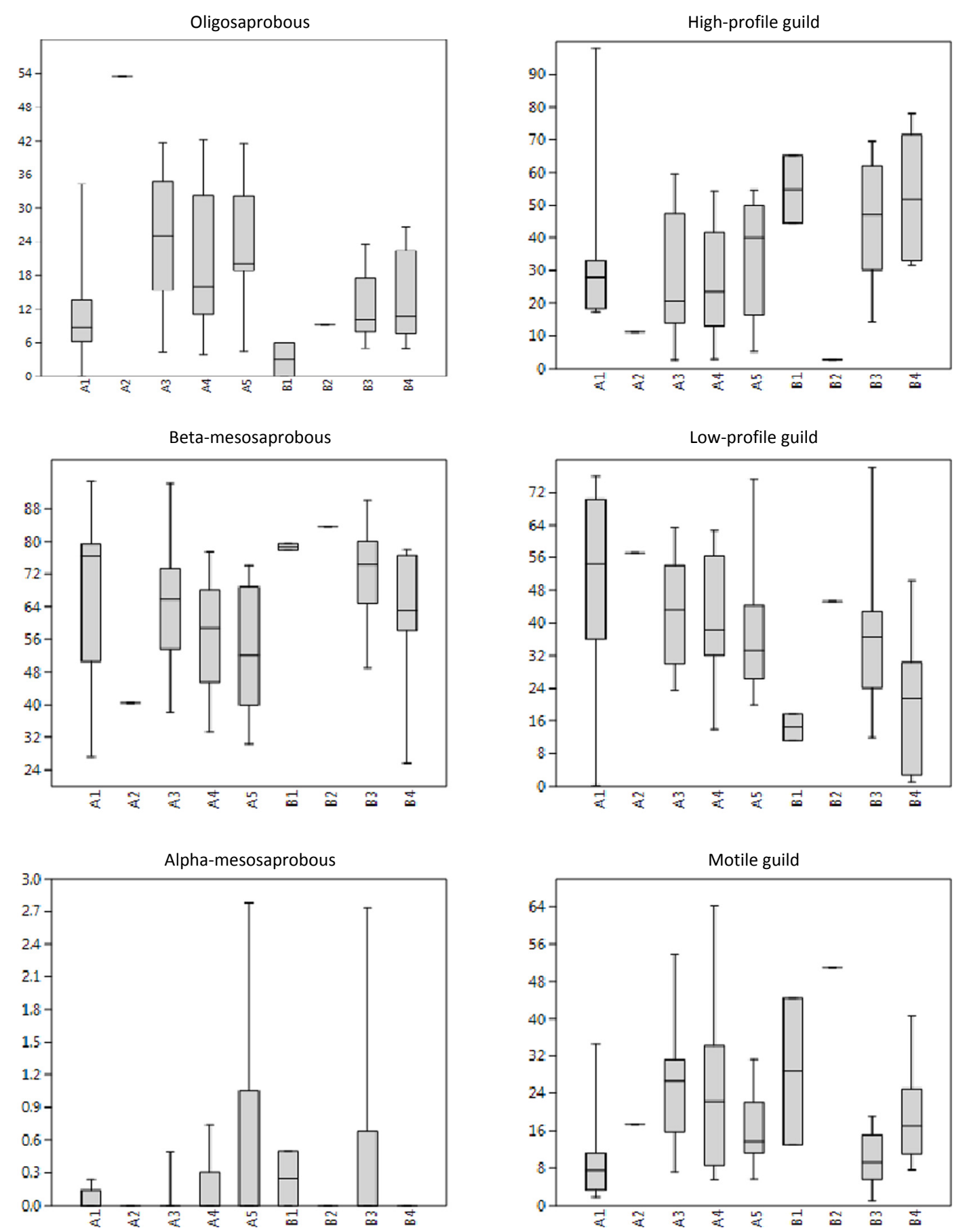

Fig. 3. Box plot of ecological guilds and saprobic classes (Van et al., 1994) abundances (\%) in each diatom community. 25th and 75 th percent quartiles are drawn using a box, median is shown with a horizontal line inside the box, minimal and maximal values are shown with whiskers.

to all the other lakes is their very special species composition. Indeed, three out of nine of their indicative species are aerophilic. It is the case of Pinnularia borealis which is quite common in soils (Ciniglia et al., 2007) and dry environments (Van de Vijver and Beyens, 1999; Sonneman, 2000). Hantzchia. amphioxys is also a species that easily resists dry periods (e.g. Souffreau et al., 2013). And finally Diadesmis contenta var. biceps is also aerophilic (e.g.Van De Vijver and Beyens, 1999; Lowe et al., 2014). We can assume that the high abundances of aerophilic diatoms can be related to possible fluctuations of the water level drying an important area of the littoral zone, and therefore favouring such diatom species.

A second diatom community, (B2) presents similar ecological features. It has a high abundance of Adlafia muralis ( $17 \%$ of the diatom community) which is subaerial species (Van et al., 1994), able to resist to shorter dry periods than species of group B1. As well as group B1, we can assume the abundance of this species is explained by water levels fluctuations. 

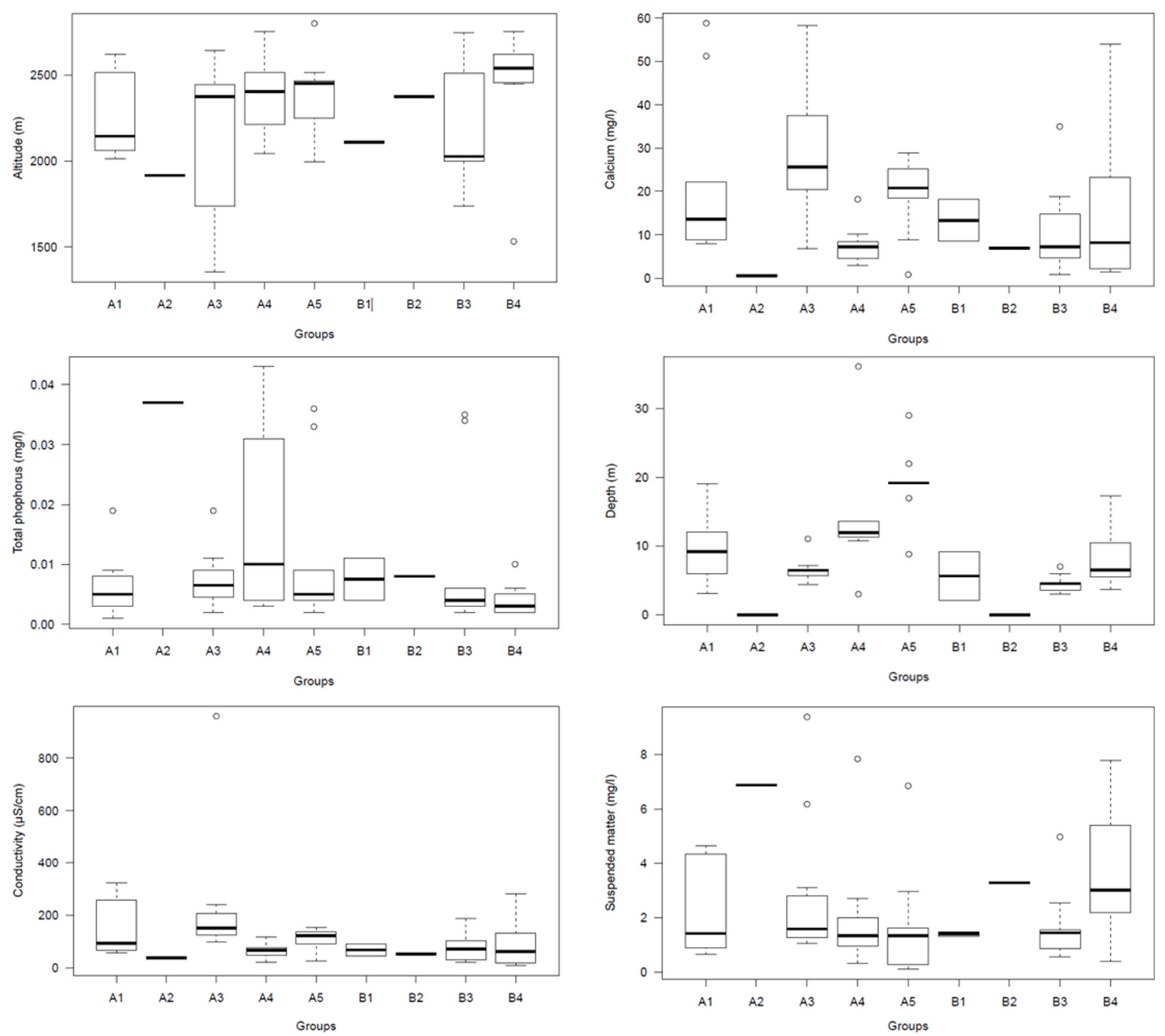

Fig. 4. Box-plot of environmental parameters for the 9 diatom assemblages.

\subsubsection{Diatom communities of shallow high altitudes lakes (B3)}

These diatom communities are present in the shallowest lakes $(3.0-7.0 \mathrm{~m})$ of this study (apart lakes of diatom communities A2 and B2). It is composed mostly by lowprofile $(41.9 \%)$ and high-profile species $(40.7 \%)$. Dominant species are A. minutissimum, E. minutum, E. subminuta and $E$. ventricosum. This cluster has no indicative species.

\subsubsection{Diatoms communities of the highest altitude lakes with high suspended matter concentrations (B4)}

This diatom community is present in the highest altitudes lakes $(2371 \mathrm{~m}$ on average) which also present the highest suspended matter concentrations $(2.63 \mathrm{mg} / 1$ on average). These high suspended matter concentrations may explain the presence of two particular indicative species, Nitzschia acidoclinata and Navicula exilis, which belong to genera known to prefer waters with high suspended matter (Battegazzore et al., 2003). Moreover, these two species are characteristic of slightly acidic waters (Bey and Ector, 2013). The other dominant species (E. minutum, E. ventricosum, $A$. minutissimum) are indicators of oligotrophic waters (e.g. Van et al., 1994).

\subsection{Local factors impact more diatom communities composition than regional factors}

Geology was an important parameter to consider to explain diatom species composition in our study area but its importance was secondary compared to the other parameters such as lake's depth, altitude and suspended matter. We could distinguish communities occurring in lakes with a calcareous watershed (A5) from communities occurring in lakes with a siliceous 

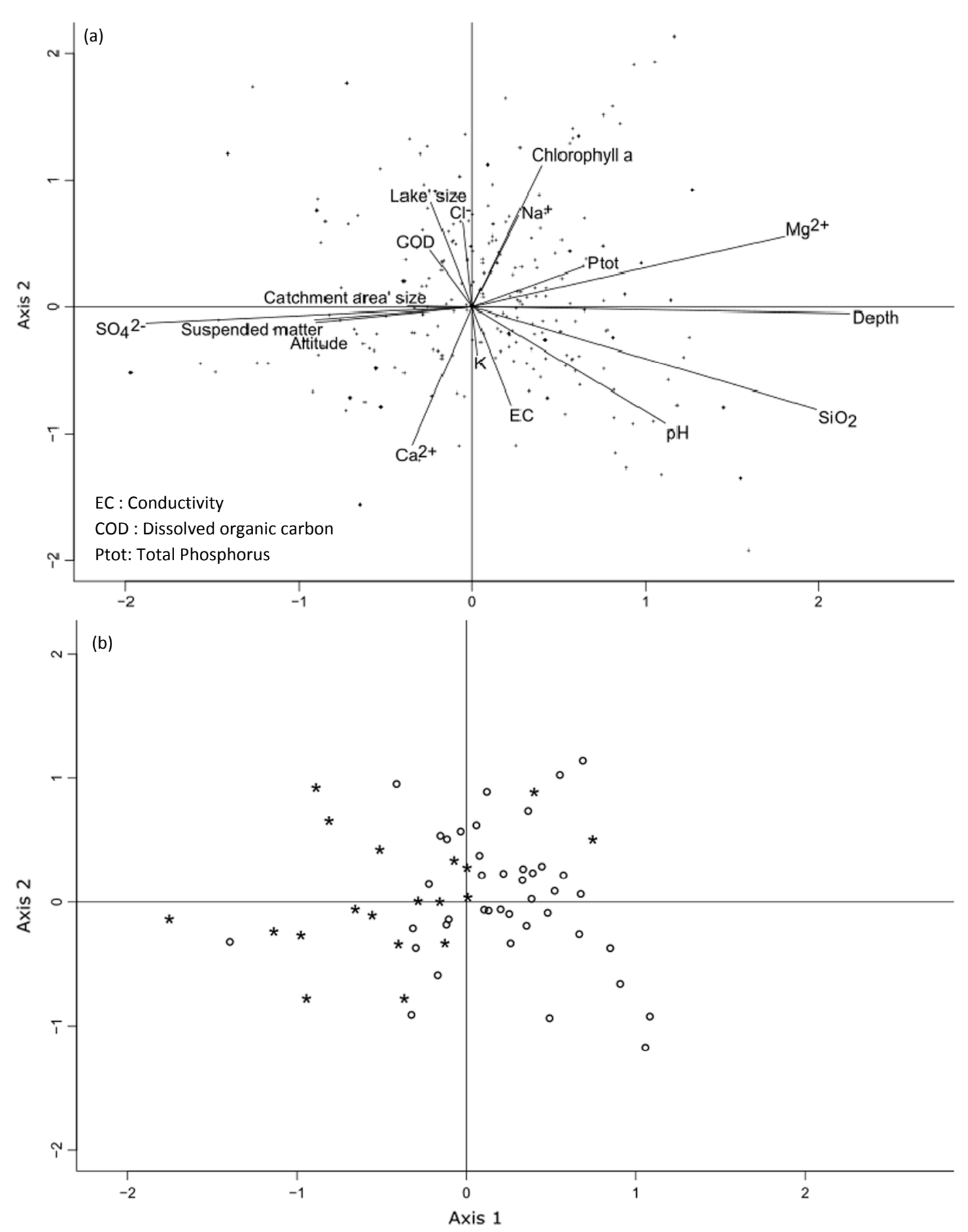

Fig. 5. Ordination diagrams for Canonical Correspondance Analyse (CCA). (a) Species and parameters, axis 1 and 2 respectively explain 13.45 and $10.66 \%$ of inertia, (b) lakes and their diatom community belonging: A $\left(^{\circ}\right)$ or B $(*)$.

watershed (A2 and A4). Such discrimination between diatom communities living in contrasted geologies (crystalline $v s$. sedimentary geologies) has already been mentioned several times in rivers from several countries such as U.S.A, France, Luxembourg (e.g. Rimet et al., 2004; Tison et al., 2004; Weilhoefer and Pan, 2006; Rimet, 2009). It was also mentioned in high altitude lakes in Europe for sub-fossil diatoms (Kernan et al., 2009) and epilithic diatoms (Marchetto et al., 2009). Geology in rivers is often a main environmental parameter explaining diatom species composition and several authors observed that it is more important to consider than local factors such as pollution level (e.g. Rimet et al., 2004; Tison et al., 2004; Rimet, 2009). This was not the case of the lakes we studied and this can probably been explained by the often mixed geologies of the lake's basins we studied. Even if some mountain chains have homogeneous geologies and host diatom communities clearly related these geological substrates, geology of the Alps is often complex with sedimentary and crystalline rocks mixed at a local or regional scale. This situation probably hid and reduced the importance of geology to explain diatom species composition. 
The main parameters structuring benthic diatoms communities were lake's depth, altitude and suspended matters concentration. These parameters allowed to distinguished two types of lakes, deeper lakes with lower suspended matter and lower altitudes (communities A) and shallower lakes with higher suspended matter concentrations and higher altitudes (communities B). These factors vary locally. We also observed some communities presenting several aerophilic and subaerial species (B1, B2). Such communities probably occur in lakes which have an important water level fluctuation. Water level fluctuation was already observed as an important structuring factor of littoral diatom communities (Wantzen, 2008). Water level is a feature which also varies locally. Another feature which varies locally is trophic level, which enables to discriminate particular diatom communities in our study area (A4). And finally, the different diatom communities we observed were scattered in our study area and their distribution did not show a clear spatial distribution.

All these results show that local factors are more important to explain diatom communities' composition in the high altitude lakes of French Alps than regional factors. This is in accordance with other authors who also observed that local factors are more important. This is often the case when pollution -a local varying factor- masks the impact of geology in rivers (e.g. Tornés et al., 2007). Indeed, pollution is often considered as homogenising species composition (Leira and Sabater, 2005; Pan et al., 1999; Tornés et al., 2007). But pollution was not the overriding parameter in our study area since high altitude lakes are upstream most of human activities. Altitude was one of the most important structuring parameter in our study area. Indeed altitude of a high altitude lake determines its surface freezing duration ( $e$. g. Pourriot and Meybeck, 1995), which has an obvious impact on lake biology and therefore on diatom species composition. This factor of primary importance selects only a few species able to survive these extremes habitats as is has already been shown on planktonic diatom of Alpine lakes (Lotter and Bigler, 2000). UV radiations intensity is also related to altitude and also structure littoral communities (Vinebrooke and Leavitt, 1999) and this may impact diatom communities. Similarly, lake's depth was also an important structuring factor in our study area. Shallow lakes are more turbulent and this structure biological communities (e.g. Pourriot and Meybeck, 1995). Moreover, diatom of the littoral zone of the lakes are strongly impacted by physical pressures such as wave action (Stevenson and Stoermer, 1981; Hoagland and Peterson, 1990) which again confirms the importance of this locally varying factor.

\section{Conclusion}

In conclusion, the benthic diatom communities of the high altitude lakes of the French Alps did not show a spatial distribution. The most important structuring factors were varying locally and were altitude, lake's depth and suspended matter. They were not related to geology, which is often considered as an important structuring parameter for river diatoms, but to parameters which were related to physical processes, such as duration of surface water freezing or water turbulence.
Acknowledgments. We thank E. Dambrine (INRA, Université Savoie Mont-Blanc, UMR Carrtel), F. Arthaud (INRA, Université Savoie Mont-Blanc, UMR Carrtel) and C. Birks (Aster) who made possible this study.

\section{References}

Acs E, Borsodi AK, Makk J, Molnár P, Mózes A, Rusznyák A, Reskóné MN, Kiss KT. 2003. Algological and bacteriological investigations on reed periphyton in Lake Velencei, Hungary. Hydrobiol 506: 549-557.

Afnor. 2003. NF EN 13946 - Qualité de l'eau - Guide pour l'échantillonnage en routine et le prétraitement des diatomées benthiques de rivières et de plans d'eau. NF EN 13946 - Qualité de l'eau - Guide pour l'échantillonnage en routine et le prétraitement des diatomées benthiques de rivières et de plans d'eau.

Afnor. 2014. NF EN 14407 - Qualité de l'eau - Guide pour l'identification et le dénombrement des échantillons de diatomées benthiques de rivières et de lacs. NF EN 14407 - Qualité de l'eau - Guide pour l'identification et le dénombrement des échantillons de diatomées benthiques de rivières et de lacs.

APHA. 1995. Standard methods for the examination of water and wastewater. Washington, DC: American Public Health Association, $40 \mathrm{p}$.

Bahls L. 2016. Cymbella subleptoceros: Diatoms of the United States.

Battarbee RW, Grytnes JA, Thompson R, Appleby PG, Catalan J, Korhola A, Birks HJB, Heegaard E, Lami A. 2002. Comparing palaeolimnological and instrumental evidence of climate change for remote mountain lakes over the last 200 years. J Paleolimnol 28: 161-179.

Battegazzore M, Gallo L, Lucadamo L, Morisi A. 2003. Quality of the main watercourses in the Pollino National Park (Apennine Mts, S Italy) on the basis of the diatom benthic communities. Studi Trentini Sci Nat Acta Biol 80: 89-93.

Beniston M, Diaz HF, Bradley RS. 1997. Climatic change at high elevation sites: An overview. Clim Change 36: 233-251.

Bennion H, Kelly MG, Juggins S, Yallop ML, Burgess A, Jamieson J, Krokowski J. 2014. Assessment of ecological status in UK lakes using benthic diatoms. Freshw Sci 33: 639-654.

Bey MY, Ector L. 2013. Atlas des diatomées des cours d'eau de la région Rhône-Alpes - Tomes 1 à 6, DREAL Rhône-Alpes, 1182 p.

Blanco S, Ector L, Becares E. 2004. Epiphytic diatoms as water quality indicators in Spanish shallow lakes. 2/3: 71-79.

Bolla B, Borics G, Kiss KT, Reskone NM, Varbiro G, Acs E. 2010. Recommendations for ecological status assessment of lake Balaton (largest shallow lake of central europe), based on benthic diatom communities. Vie Milieu 60: 197-208.

Butcher RW. 1947. Studies in the ecology of rivers: VII. The algae of organically enriched waters. $J$ Ecol 35: 186.

Camarero L, Catalan J, Boggero A, Marchetto A, Mosello R, Psenner R. 1995. Acidification in high mountain lakes in Central, Southwest, and Southeast Europe (Alps, Pyrennees, Pirin). Limnol Jena 25: 141-156.

Camarero L, Botev I, Muri G, Psenner R, Rose N, Stuchlik E. 2009. Trace elements in alpine and arctic lake sediments as a record of diffuse atmospheric contamination across Europe. Freshw Biol 54: 2518-2532.

Cantonati M, Lowe RL. 2014. Lake benthic algae: Toward an understanding of their ecology. Freshw Sci 33: 475-486.

Cellamare M, Morin S, Coste M, Haury J. 2011. Ecological assessment of French Atlantic lakes based on phytoplankton, phytobenthos and macrophytes. Environ Monit Assess 184: 4685-4708.

Ciniglia C, Cennamo P, De Stefano M, Pinto G, Caputo P, Pollio A. 2007. Pinnularia obscura Krasske (Bacillariophyceae, Bacillar- 
iophyta) from acidic environments: characterization and comparison with other acid-tolerant Pinnularia species. Fundam Appl Limnol Arch Für Hydrobiol 170: 29-47.

Coste M, Boutry S, Tison-Rosebery J, Delmas F. 2009. Improvements of the Biological Diatom Index (BDI): Description and efficiency of the new version (BDI-2006). Ecol Indic 9: 621-650.

Crossetti LO, Stenger-Kovács C, Padisák J. 2013. Coherence of phytoplankton and attached diatom-based ecological status assessment in lake Balaton. Hydrobiol 716: 87-101.

Curtis CJ, Juggins S, Clarke G, Battarbee RW, Kernan M, Catalan J, Thompson R, Posch M. 2009. Regional influence of acid deposition and climate change in European mountain lakes assessed using diatom transfer functions. Freshw Biol 54: 2555-2572.

Dufrêne M, Legendre P. 1997. Species assemblages and indicator species: The need for a flexible asymmetrical approach. Ecol Monogr 67: 345-366.

Gomà J, Rimet F, Cambra J, Hoffmann L, Ector L. 2005. Diatom communities and water quality assessment in mountain rivers of the upper Segre basin (La Cerdanya, Oriental Pyrenees). Hydrobiol 551: 209-225.

Grimalt JO, FernáNdez P, Quiroz R. 2009. Input of organochlorine compounds by snow to European high mountain lakes: Organochlorine compounds in snow. Freshw Biol 54: 2533-2542.

Hammer Ø, Harper DAT, Ryan PD. 2015. PAST: Paleontological Statistics software package for education and data analysis. Palaeontol Electron.

Hill MO. 1979. TWINSPAN: A FORTRAN program for arranging multivariate data in an ordered two-way table by classification of the individuals and attributes. Ithaca, NY: Section of Ecology and Systematics, Cornell University, 106 p.

Hoagland KD, Peterson CG. 1990. Effects of light and wave disturbance on vertical zonation of attached microalgage in a large reservoir. J Phyco 26, 450-457.

Hofmann G, Werum M, Lange-Bertalot H. 2011. Diatomeen im Süßwasser-Benthos von Mitteleuropa: Bestimmungsflora Kieselalgen für die ökologische Praxis; über 700 der häufigsten Arten und ihre Ökologie, Gantner, 908 p.

Hustedt F. 1957. Die Diatomeenflora des Fluss-systems der Weser im Gebiet der Hansestadt Bremen. Otto Koeltz Science Publishers, 441 p.

Jones VJ, Flower RJ, Appleby PG, Natkanski J, Richardson N, Rippey B, Stevenson AC, Battarbee RW. 1993. Palaeolimnological evidence for the acidification and atmospheric contamination of lochs in the Cairngorm and Lochnagar Areas of Scotland. J Ecol 81: 3-24.

Kernan M, Ventura M, BitušíK P, Brancelj A, Clarke G, Velle G, Raddum GG, StuchlíK E, Catalan J. 2009. Regionalisation of remote European mountain lake ecosystems according to their biota: Environmental versus geographical patterns: Environmental versus geographical drivers in mountain lakes. Freshw Biol 54: 2470-2493.

King L, Clarke G, Bennion H, Kelly M, Yallop M. 2006. Recommendations for sampling littoral diatoms in lakes for ecological status assessments. J Appl Phycol 18: 15-25.

Kolkwitz R, Marsson M. 1908. Ökologie der pflanzlichen Saprobien. Berichte Dtsch Bot Ges 26: 505-519.

Krammer K. 1997a. Bibliotheca Diatomologica Band 36 Die Cymbelloiden Diatomeen Eine Monographie Der Weltweit Bekannten Taxa Teil 1. Allgemeines und Encyonema Part, J. Cramer, $382 \mathrm{p}$.

Krammer K. 1997b. Bibliotheca Diatomologica Band 37 Die Cymbelloiden Diatomeen Eine Monographie Der Weltweit Bekannten Taxa Teil 2. Encyonema Part, Encyonopsis and Cymbellopsis, J. Cramer, 469 p.

Krammer K. 2000. Diatoms of Europe. Diatoms of the European Inland Waters and Comparable Habitats. Vol. 4. Cymbopleura, Delicata,
Navicymbula, Gomphocymbellopsis, Afrocymbella Supplements to cymbelloid taxa., Ruggell. Königstein/Germany, 534 p.

Krammer K. 2002. Diatoms of Europe: diatoms of the european inland waters and comparable habitats, Vol. 3. Cymbella., Gantner Verlag, Ruggell, 584 p.

Krammer K, Lange-Bertalot H. 1997. Süßwasserflora von Mitteleuropa, Bd. 02/2: Bacillariophyceae: Teil 2: Bacillariaceae, Epithemiaceae, Surirellaceae. Heidelberg: Spektrum Akademischer Verlag, 612 p.

Krammer K, Lange-Bertalot H. 2004. Süßwasserflora von Mitteleuropa, Bd. 02/4: Bacillariophyceae: Teil 4: Achnanthaceae, Kritische Ergänzungen zu Achnanthes s.l., Navicula s.str. Heidelberg u.a.: Spektrum Akademischer Verlag, 468 p.

Krammer K, Lange-Bertalot H. 2010. Susswasserflora von Mitteleuropa, Bd. 2/1: Bacillariophyceae, Teil 1: Naviculaceae. Heidelberg: Spektrum Akademischer Verlag, 440 p.

Krammer K, Lange-Bertalot H, Hakansson H, Nörpel M. 2008. Bacillariophyceae: Teil 3: Centrales, Fragilariaceae, Eunotiaceae. Heidelberg: Spektrum Akademischer Verlag, 600 p.

Lange-Bertalot H, Moser G. 1994. Brachysira. Monographie der Gattung, $212 \mathrm{p}$.

Lange-Bertalot H, Hofmann G, Werum M. 2013. Diatomeen im Süßwasser - Benthos von Mitteleuropa. Bestimmungsflora Kieselalgen für die ökologische Praxis. Über 700 der häufigsten Arten und ihre Ökologie. Von Gabriele Hofmann, Marcus Werum und Horst Lange-Bertalot. Königstein: Koeltz Scientific Books, 908 p.

Leira M, Sabater S. 2005. Diatom assemblages distribution in catalan rivers, NE Spain, in relation to chemical and physiographical factors. Water Res 39: 73-82.

Lotter AF, Bigler C. 2000. Do diatoms in the Swiss Alps reflect the length of ice-cover? Aquat Sci 62: 125-141.

Lowe RL, Kociolek P, Johansen JR, Vijver BVD, Lange-Bertalot H, Kopalová K. 2014. Humidophila gen. nov., a new genus for a group of diatoms (Bacillariophyta) formerly within the genus Diadesmis: Species from Hawai, including one new species. Diatom Res 29: 351-360.

Magnea U, Sciascia R, Paparella F, Tiberti R, Provenzale A. 2013. A model for high-altitude alpine lake ecosystems and the effect of introduced fish. Ecol Model 251: 211-220.

Mann DG, Droop SJM. 1996. Biodiversity, biogeography and conservation of diatoms. Hydrobiol 336: 19-32.

Mann DG, Vanormelingen P. 2013. An inordinate fondness? The number, distributions, and origins of diatom species. $J$ Eukaryot Microbiol 60: 414-420.

Marchetto A, Rogora M, Boggero A, Lotter A, Tolotti M, Hansjorg T, Psenner R, Massafero J, Barbieri A. 2009. Response of alpine lakes to major environmental gradients, as detected through planktonic, benthic and sedimentary assemblages. Adv Limnol 62: 419-440.

Marchetto A, Agostinelli C, Alber R, Behi A, Balsamo S, Bracchi S. 2013. Indice per valutazione della qualità delle acque lacustriitaliane a partire dalle diatomee epifitiche ed epilitiche (EPI-L), 75-92.

McCune B, Mefford J. 2006. PC-ORD. Multivariate Analysis of Ecological Data. Version 5.18. Software. Oregon, USA: Gleneden Beach.

Meteo France. 2016. METEO FRANCE - Découpage de l'Hexagone en 29 zones aux caractéristiques climatiques homogènes. Available at http://pluiesextremes.meteo.fr/un-decoupage-climatique-de-lafrance-en-29-zones_r197.html (accessed on 12.05.16)

Mielke PW, Berry KJ, Brier GW. 1981. Application of multi-response permutation procedures for examining seasonal changes in monthly mean sea-level pressure patterns. Mon Weather Rev 109: 120-126.

Millennium Ecosystem Assessment (Program). 2005. Ecosystems and human well-being: wetlands and water synthesis: a report of the Millennium Ecosystem Assessment. Washington, DC: World Resources Institute, 68 p. 
Organisation de coopération et de développement économiques. 1982. Eutrophisation des eaux: méthodes de surveillance, d'évaluation et de lutte, OCDE (Paris).

Ostendorp W, Iseli C, Krauss M, Krumscheid-Plankert P, Moret J-L, Rollier M, Schanz F. 1995. Lake shore deterioration, reed management and bank restoration in some Central European lakes. Ecol Eng 5: 51-75.

Pan Y, Stevenson RJ, Hill BH, Kaufmann PR, Herlihy AT. 1999. Spatial patterns and ecological determinants of benthic algal assemblages in Mid-Atlantic streams, USA. J Phycol 35: 460-468.

Pan Y, Stevenson RJ, Hill BH, Herlihy AT. 2000. Ecoregions and benthic diatom assemblages in Mid-Atlantic highlands streams, USA. J North Am Benthol Soc 19: 518-540.

Parker BR, Vinebrooke RD, Schindler DW. 2008. Recent climate extremes alter alpine lake ecosystems. Proc Natl Acad Sci 105: 12927-12931.

Parlement européen et al. 2000. Directive Cadre européenne sur l'Eau 2000/60/CE. Directive Cadre européenne sur l'Eau 2000/60/CE.

Patrick S, Battarbee RW, Wathne B, Psenner R. 1998. Measuring and modelling the dynamic response of remote mountain lake ecosystems to environmental change: an introduction to the MOLAR project. IAHS Publ 248: 403-410.

Potapova M, Charles DF. 2007. Diatom metrics for monitoring eutrophication in rivers of the United States. Ecol Indic 7: 48-70.

Pourriot R, Meybeck M. 1995.Limnologie générale. Paris, 965 p.

Reichardt E. 1997. Bermerkenswerte Diatomeenfunde aus Bayern IV. Zwei Neue Arten Aus Den Kleinen Ammerquellen Berichte Bayer. Bot. Ges. Zur Erforsch. Heim Flora 68: 61-66.

Rimet F. 2009. Benthic diatom assemblages and their correspondence with ecoregional classifications: Case study of rivers in northeastern France. Hydrobiol 636: 137-151.

Rimet F, Bouchez A. 2012a. Biomonitoring river diatoms: Implications of taxonomic resolution. Ecol Indic 15: 92-99.

Rimet F, Bouchez A. 2012b. Life-forms, cell-sizes and ecological guilds of diatoms in European rivers. Knowl Manag Aquat Ecosyst 406: 1-14.

Rimet F, Tudesque L, Peeters V, Vidal H, Ector L. 2003. Assemblages-types de diatomées benthiques des rivières nonpolluées du bassin Rhône-Méditerranée-Corse (France). Bull Société Sci Nat Ouest Fr $2^{\text {ème }}$ supplément hors série 272-287.

Rimet F, Ector L, Cauchie HM, Hoffmann L. 2004. Regional distribution of diatom assemblages in the headwater streams of Luxembourg. Hydrobiol 520: 105-117.

Rimet F, Ector L, Cauchie H-M., Hoffmann L. 2009. Changes in diatom-dominated biofilms during simulated improvements in water quality: implications for diatom-based monitoring in rivers. Eur J Phycol44: 567-577.

Rimet F, Bouchez A, Montuelle B. 2015. Benthic diatoms and phytoplankton to assess nutrients in a large lake: Complementarity of their use in Lake Geneva (France-Switzerland). Ecol Indic 53: 231-239.

Rimet F, Bouchez A, Tapolczai K. 2016. Spatial heterogeneity of littoral benthic diatoms in a large lake: monitoring implications. Hydrobiol 771: 179-193.

Sabater S, Roca JR. 1992. Ecological and biogeographical aspects of diatom distribution in Pyrenean springs. Br Phycol J 27: 203-213.

Schaumburg J, Schranz C, Stelzer D, Hofmann G. 2007. Action instructions for the ecological evaluation of lakes for implementation of the EU Water Framework Directive: Makrophytes and Phytobenthos. Bavar Environ Agency, 69 p.
Soininen J. 2004. Determinants of benthic diatom community structure in Boreal streams: The role of environmental and spatial factors at different scales. Int Rev Hydrobiol 89: 139-150.

Soininen J. 2012. Macroecology of unicellular organisms - patterns and processes: Macroecology of unicellular organisms. Environ Microbiol Rep 4: 10-22.

Sonneman JA. 2000. An illustrated guide to common stream diatom species from temperate Australia. Thurgoona, N.S.W: Cooperative Research Centre for Freshwater Ecology, 168 p.

Souffreau C, Vanormelingen P, Van de Vijver B, Isheva T, Verleyen E, Sabbe K, Vyverman W. 2013. Molecular evidence for distinct Antarctic lineages in the cosmopolitan terrestrial diatoms Pinnularia borealis and Hantzschia amphioxys. Protist 164: 101-115.

Stenger-Kovács C, Buczkó K, Hajnal É, Padisák J. 2007. Epiphytic, littoral diatoms as bioindicators of shallow lake trophic status: Trophic Diatom Index for Lakes (TDIL) developed in Hungary. Hydrobiol 589: 141-154.

Stevenson RJ. 1998. Diatom indicators of stream and wetland stressors in a risk management framework. Environ Monit Assess 51: 107-118.

Stevenson RJ, Stoermer EF. 1981. Quantitative differences between benthic algal communities along a depth gradient in lake Michigan. J Phycol 17: 29-36.

Tison J, Giraudel JL, Coste M, Park Y-S., Delmas F. 2004. Use of unsupervised neural networks for ecoregional zoning of hydrosystems through diatom communities: case study of AdourGaronne watershed (France). Arch Für Hydrobiol 159: 409-422.

Tornés E, Cambra J, Goma J, Leira M, Ortiz R, Sabater S. 2007. Indicator taxa of benthic diatom communities: A case study in Mediterranean streams. Ann Limnol-Int J Limnol 43: 1-11.

Tudesque L, Rimet F, Ector L. 2008. A new taxon of the section Nitzschiae lanceolatae Grunow: Nitzschia costei sp. nov. compared to N. fonticola Grunow, N. macedonica Hustedt, N. tropica Husted and related species. Diatom Res 23: 483-501.

Van Dam H, Mertens A, Sinkeldam J. 1994. A coded checklist and ecological indicator values of freshwater diatoms from the Netherlands. Aquat Ecol 28: 117-133.

Van de Vijver B, Beyens L. 1999. Freshwater diatoms from Ile de la Possession (Crozet Archipelago, sub-Antarctica): an ecological assessment. Polar Biol 22: 178-188.

Van de Vijver B, Jarlman A, Lange-Bertalot H, Mertens A, de Haan M, Ector L. 2011. Four new European Achnanthidium species (Bacillariophyceae). Algol Stud 136: 193-210.

Vinebrooke RD, Leavitt PR. 1999. Differential responses of littoral communities to ultraviolet radiation in an Alpine lake. Ecology 80: 223-237.

Vyverman W, Verleyen E, Sabbe K, Vanhoutte K, Sterken M, Hodgson DA, Mann DG, Juggins S, Vijver BV de, Jones V, et al., 2007. Historical processes constrain patterns in global diatom diversity. Ecology 88: 1924-1931.

Wantzen KM. 2008. Ecological effects of water-level fluctuations in lakes. Hydrobiol 613: 1-183.

Weilhoefer CL, Pan Y. 2006. Diatom assemblages and their associations with environmental variables in Oregon coast range streams, USA. Hydrobiol 561: 207-219.

Zaharescu DG, Burghelea CI, Hooda PS, Lester RN, Palanca-Soler A. 2016. Small lakes in big landscape: Multi-scale drivers of littoral ecosystem in alpine lakes. Sci Total Environ 551-552: 496-505.

Zelinka M, Marvan P. 1961. Zur Prazisierung der biologischen Klassifikation der Reinheit fliessender Gewasser.

Cite this article as: Feret L, Bouchez A, Rimet F. 2017. Benthic diatom communities in high altitude lakes: a large scale study in the French Alps. Ann. Limnol. - Int. J. Lim. 53: 411-423 